December 2008

\title{
Churchill in Munich: The Paradox of Genocide Prevention
}

Robert Melson

Follow this and additional works at: https://digitalcommons.usf.edu/gsp

\section{Recommended Citation}

Melson, Robert (2008) "Churchill in Munich: The Paradox of Genocide Prevention," Genocide Studies and Prevention: An International Journal: Vol. 3: Iss. 3: Article 5.

Available at: https://digitalcommons.usf.edu/gsp/vol3/iss3/5

This Articles is brought to you for free and open access by the Open Access Journals at Digital Commons @ University of South Florida. It has been accepted for inclusion in Genocide Studies and Prevention: An International Journal by an authorized editor of Digital Commons @ University of South Florida. For more information, please contact digitalcommons@usf.edu. 


\title{
Churchill in Munich: The Paradox of Genocide Prevention
}

\author{
Robert Melson \\ Strassler Center for Holocaust and Genocide Studies, Clark \\ University
}

A catastrophe averted is likely not to be viewed as a catastrophe. A predicted event that fails to materialize is a non-event, something that did not happen, and politicians who expend wealth and lives on something that fails to happen cannot expect to reap the rewards of their decisions. Quite to the contrary, politicians who spend lives and treasure to prevent catastrophes such as genocide are likely to be vilified and punished for their efforts: to the extent that their actions succeed in averting a catastrophe, there is no proof of their success, only of the costs of their efforts. This last point is especially intriguing, and it goes to the heart of the paradox of genocide prevention.

Consider the famous case of Winston S. Churchill. Had he, instead of Neville Chamberlain, been Britain's prime minister in the 1930s, and thus gone to Munich to meet Adolf Hitler in 1938, there is a good chance that World War II would have been averted and the Holocaust prevented. The irony is that had Churchill been successful in preventing war and genocide, the British public would not know about his triumph, because there would be no evidence for it. All the public would be sure of was that Churchill had brought the world to the brink of war, and he would be blamed for that. The further irony is that, had Churchill succeeded in preventing the war, he might have gone down in history as an erratic warmonger rather than as the greatest war leader of the Western world.

Keywords: genocide prevention, Holocaust, World War II, paradox of genocide prevention

\section{Introduction}

After World War II and the Holocaust, politicians in democratic societies professed their commitment to the prevention of genocide; despite their claim of "never again," however, they have seldom acted on their promises. Their excuse has often been that they do not know enough about a particular situation, or that there is not enough support for concerted action to prevent genocide. When war and genocide loomed in Rwanda in 1993-1994, and concerted action could have prevented catastrophe, few wanted to take the risk of prevention or intervention. ${ }^{1}$ As Samantha Power suggests, politicians do not want to expend lives and wealth on a venture that will involve great risk and very little political profit. ${ }^{2}$ Hence, despite appearances, the lack of intervention to prevent genocide is not a recurring failure of policy-it is policy. It is a successful policy of non-intervention. Following this line of thought, I argue here that politicians hesitate to prevent catastrophe in general, and genocide in particular, because if they act decisively and yet fail to prevent a humanitarian catastrophe they can be blamed for the failure, whereas if they succeed at prevention they are likely not to be rewarded for their success. On the contrary, in fact, they are likely to be politically punished for prevention that succeeds. The last point is especially intriguing

Robert Melson, "Churchill in Munich: The Paradox of Genocide Prevention." Genocide Studies and Prevention 3, 3 (December 2008): 297-308. (C) 2008 Genocide Studies and Prevention. doi:10.3138/gsp.3.3.297 
and goes to the heart of what I call "the paradox of catastrophe and genocide prevention."

A catastrophe averted is likely not to be seen as a catastrophe. A predicted event that fails to materialize is a non-event, something that did not happen, and politicians who have expended wealth and lives on something that failed to happen cannot be expected to reap the rewards of their decisions. On the contrary, politicians who risk lives and wealth to avert catastrophes such as genocide run the risk of being vilified and punished for their efforts: To the extent that their actions succeed in averting a catastrophe, there will be no evidence of their success-only of the costs of their efforts. This essay uses counterfactual-“what if"-arguments to explore some of the structural obstacles to the prevention of genocide. ${ }^{3}$

Consider the famous case of Winston S. Churchill. Churchill believed that had he, instead of Neville Chamberlain, been prime minister of Britain in the 1930s, and if he had stood up to Adolf Hitler during the Rhineland crisis of 1936 or gone to Munich not to mollify but to warn Hitler in 1938, there is a good chance that World War II would have been averted and the Holocaust prevented. Unlike Chamberlain, Churchill would never have sold out Czechoslovakia, and he could have rallied France and the Soviet Union against the Nazis. Indeed, even as late as the Munich crisis, as he notes in The Gathering Storm, Churchill believed that had the Allies been united, the German military might have staged a coup against Hitler, and thus prevented the war. ${ }^{4}$ Moreover, since most historians now believe that the Holocaust was a direct by-product of the radicalization of Nazi policies during the war, it follows that averting the latter would have prevented the former. ${ }^{5}$

Of course, even his was a counterfactual speculation-a "what if?" propositionand the great Churchill might have been proven wrong. Counterfactual constructions lend themselves to many different possibilities. Had Churchill gone to Munich, he might not have been able to prevent the war, and if war had started in 1938, the result might have been the triumph of the Germans and the Nazi occupation of Britain. Indeed, that is the speculation of Andrew Roberts and Niall Ferguson, two wellregarded British historians. ${ }^{6}$ If they are right, the timing of the war and the Holocaust might have been different but the catastrophe would not have been averted.

In this essay I assume that Churchill and not his doubters had it right: that had he been prime minister in the 1930s, he would have averted war and genocide by containing and deterring the Germans through an alliance of Britain, France, and the Soviet Union. What Churchill did not take into account, however, is the likelihood that he would have paid a price at the polls in the next election for threatening war or precipitating war-unlike Chamberlain, who claimed that he had "brought peace in our time." Pacifist, anti-Communist, and even some pro-German sentiment ran strong in Britain in the 1930s. The likelihood is that Churchill would now be remembered not as one of the greatest leaders of the Western world but as an adventurer and warmonger, a very different Churchill from the one we know and praise today. That would have been the paradox of Churchill's prevention of World War II, and thereby of the Holocaust.

In The Gathering Storm, the first volume of his memoir of World War II, Churchill recalls that when President Roosevelt asked for suggestions about what the war should be called, he unhesitatingly replied, "the Unnecessary war." Churchill then goes on,

There never was a war more easy to stop than that which has just wrecked what was left of the world from the previous struggle ... It is my earnest hope that pondering 
upon the past may give guidance in days to come, enable a new generation to repair some of the errors of former years, and thus govern, in accordance with the needs of the glory of man. ${ }^{7}$

The trouble is that no generation seems to know how to learn from the past and avoid the catastrophes of the future. In the context of uncertainty, ambiguity, and unintended consequences that is the future, political leaders do not wish to incur the costs of prevention. These costs may be too high, endangering their political survival, while the political benefits may be too low or even non-existent.

In what follows I briefly sketch the path to war and genocide and Churchill's warnings along the way, from Hitler's rise to power through German rearmament, the Rhineland crisis, the Anschluss of Austria, and the Munich Agreement to the start of World War II. I conclude by suggesting-thereby illustrating the paradox of prevention-that had he been successful in preventing the war, Churchill would likely have been repudiated at the polls for his efforts.

\section{Hitler's Rise to Power}

In the late 1920s and early 1930s, the Great Depression, the rise of the Communist Party of Great Britain, and fear of Communism led many upper-class Tories to feel sympathy for Fascism and for the rise of Nazism in Germany, which they viewed as a bulwark against Bolshevism. ${ }^{8}$ Meanwhile, the Labour and Liberal parties, reflecting public opinion, were thoroughly pacifist, even as the Nazis began their climb to power. This was also the period when the United States, having rejected membership in the League of Nations despite the support of President Woodrow Wilson, had taken a politically isolationist turn under the subsequent administrations of Warren Harding, Calvin Coolidge, Herbert Hoover, and Franklin Delano Roosevelt. But the leaders of other democracies were also pacifist or were disengaged from foreign affairs, leaving the diplomats to draw up such largely meaningless international covenants as the Treaty of Locarno (1 December 1925), which guaranteed German-French and German-Belgian borders and provided for arbitration in international crises, and the Kellogg-Briand Pact (27 August 1928) outlawing war, which was signed by fifteen nations including Britain, France, and Germany.

In the election of 14 September 1930, the Nazis won 107 of 577 seats in the Reichstag. This was the beginning of their breakthrough to power by legal means, and from then on in Hitler played a major role in German politics. In the 30 July 1932 elections the Nazis won 230 seats and became the largest single party in the Reichstag. On 17 October 1932, months before Hitler came to power, Churchill was already warning in the Daily Mail about German rearmament: "Do not let his Majesty's Government believe ... that all Germany is asking for is equal status ... They are asking for weapons." 9 But the country was not yet ready to listen to him; nor was it yet disgusted by Nazi anti-Semitism, as he already was by $1932 .{ }^{10}$

On 30 January 1933, Hitler became Chancellor of Germany. Ten days later, on 9 February, the Oxford Union voted 275 to 153 for the following resolution: "This House will in no circumstances fight for King and Country." ${ }^{11}$ In the London Times of 18 February, Churchill called this expression of student opinion an "abject, squalid, shameless avowal ... a very disquieting and disgusting symptom." Citing young Nazis in Germany and fascisti in Italy, he said, "One can almost feel the curl of contempt upon the lips of the manhood of all these peoples when they read this message sent out by Oxford University in the name of young England." ${ }^{12}$ British elite public opinion had not yet taken the measure of Nazism, but Churchill had. 


\section{Churchill's Views on the Looming Crisis in British Rearmament}

The military and diplomatic crisis with Germany in the 1930s involved Germany's cancellation of key provisions of the Versailles treaties, accelerated rearmament, expansionism, and irredentism culminating in war. Meanwhile, in 1934 anti-war and anti-rearmament candidates swept by-elections in Britain. Alarmed, Churchill warned Parliament that unilateral disarmament would be madness, but Stanley Baldwin, then prime minister, adjusted government principles and strategy to the country's pacifist mood. On 4 March 1935, His Majesty's Government (HMG) announced increases in appropriation for the air force that Churchill thought were too little too late. In addition, the Labour Party moved to censure the government for even recommending such increases, viewing them as unnecessary and provocative. On 16 March 1935, Hitler announced that all German youths were subject to conscription, in violation of the Versailles treaties. He gambled that neither the British nor the French would challenge him, and he was right. Meanwhile, the League of Nations condemned German rearmament but rejected all motions calling for sanctions. ${ }^{13}$ On 19 March 1935, HMG announced that, given the new appropriations, British air power would be superior to that of Germany. Citing his own sources, Churchill strenuously disagreed and warned of Britain's vulnerability: "At the end of the year, when we were to have had a 50 percent superiority over Germany, they will be at least three and four times as strong as we."14

It was in this context of accelerated German rearmament that, on 12 March 1935, Churchill addressed the Conservative Backbench Foreign Affairs Committee of the House of Commons. In this address he formulated his opposition to the rise of Nazi Germany in terms of traditional British interests, which historically were to oppose the emergence of a powerful threat on the continent by leading an alliance of lesser powers against the challenger. In effect, he outlined his strategic vision for a world challenged by an aggressive Germany rising in the heart of Europe:

For four hundred years the foreign policy of England had been to oppose the strongest, most aggressive, most dominating Power on the Continent, and particularly to prevent the Low Countries falling into the hands of such a Power ... Faced by Philip II of Spain, against Louis XIV under William III and Marlborough, against Napoleon, against William II of Germany, it would have been easy and must have been very tempting to join with the stronger and share the fruits of his conquest. However, we always took the harder course, joined with the less strong Powers, made a combination among them, and thus defeated and frustrated the Continental military tyrant whoever he was, whatever nation he led ... All our thoughts rest in that tradition today. I know of nothing which has occurred to alter or weaken the justice, wisdom, valour, and prudence upon which our ancestors acted....

The question, therefore, arises which is today the power in Europe which is the strongest, and which seeks in a dangerous and oppressive sense to dominate ... [Germany] is arming in a manner which has never been seen in [her] history. She is led by a handful of triumphant desperadoes ... Very soon they will have to choose, on the one hand, between economic and financial collapse or internal upheaval, and, on the other, a war which could have no other object, and which if successful, can have no other result than a Germanised Europe under Nazi control. Therefore, it seems to me that all the old conditions present themselves again, and that our national salvation depends upon our gathering once again all the forces of Europe to contain and restrain, and if necessary to frustrate, German domination. ${ }^{15}$

On 25 March 1935, Hitler announced that Germany had reached parity with Britain in the air. The Baldwin government remained unresponsive. 


\section{Rhineland, 1936}

On 7 March 1936 the Rhineland was reoccupied by Germany, in violation of the Treaty of Versailles. It was then, Churchill believed, that, had he been prime minister, he might have halted the march toward war. By Munich, in his view, it was probably too late. On 26 March 1936, in the House of Commons, he noted that

in spite of the seriousness which I attach to this reoccupation of the Rhineland, I must say that it seems to me the smallest part of the whole problem. What is the real problem, the real peril? It is not the reoccupation of the Rhineland, but this enormous process of the rearmament of Germany. There is the peril ... I confess that I have been occupied with this idea of the great wheels revolving and the great hammers descending day and night in Germany, making the whole industry of that country an arsenal, making the whole of that gifted and valiant population into one great disciplined war machine ... There is what is bringing the war. ${ }^{16}$

He went on to ask, rhetorically, "How are we going to stop this war which seems to be moving towards us in so many ways?"17

His answer, one to which he turned again and again, was to strengthen Britain's alliance with France and to create a system of collective security, including the Soviet Union, under the League of Nations. ${ }^{18}$ Churchill sought to prevent the looming war by what has come to be known in today's parlance as deterrence and containment. He did not seek war with Germany; he sought to prevent war, but in vain.

\section{Anschluss, 1938}

To counter Hitler's pressure on Austria to join the German Reich, Prime Minister Kurt Schuschnigg of Austria called for a plebiscite. On 11 March 1938, Lord Halifax, who had replaced Anthony Eden as foreign secretary, cabled Schuschnigg to warn him that Britain would not come to his aid should the Germans strike. The same day, Italy announced that it would not aid in preserving Austria's independence. Schuschnigg then resigned, and on 13 March German troops marched into Austria. The next day, thousands of Jews and purported enemies of the Nazi regime were sent to concentration camps. Many were killed.

Neville Chamberlain came to the House of Commons on 14 March and promised to accelerate British rearmament. Churchill responded that unless actions followed words, a strategy of collective security to stop the Nazis would be too late:

The gravity of the events of the 11th of March cannot be exaggerated. Europe is confronted with a programme of aggression, nicely calculated and timed, unfolding stage by stage, and there is only one choice open ... either to submit, like Austria, or else take effective measures while time remains. ${ }^{19}$

In the same speech he went on to warn about Czechoslovakia, which, after the Anschluss, was surrounded by Germany on three sides. "No doubt," he noted ironically,

they are only a small democratic State, no doubt they have an army only two or three times as large as ours, no doubt they have a munitions supply only three times as great as that of Italy, but still they are a virile people; they have their treaty rights, they have a line of fortresses, and they have strongly manifested a will to live freely. ${ }^{20}$

Churchill was outraged by the Anschluss and the looming threat to Czechoslovakia, not only because it fortified the Nazis and weakened Britain but 
because it undermined the world order created after World War I, which was best expressed by the League of Nations:

I affirm that the Government should express in the strongest terms our adherence to the Covenant of the League of Nations and our resolve to procure by international action the reign of law in Europe ... There must be a moral basis for British rearmament and British foreign policy. We must have that basis if we are to unite and inspire our people ... and if we are to stir the English-speaking people throughout the world. ${ }^{21}$

Churchill argued not for war against Germany but for collective security in the context of the League of Nations, for a "grand alliance" that might deter Nazi aggression and become the best guarantor of peace in Europe. This grand alliance would be led by Britain and France and would include the smaller European states.

If that were sustained, as it would be by the moral sense of the world; and if it were done in 1938 - and believe me, it may be the last chance there will be for doing it—-then I say that you might even now arrest this approaching war. ${ }^{22}$

On 18 March 1938, a week after the German incorporation of Austria, the Cabinet met to consider the implications of the Anschluss and its threat to Czechoslovakia. Minister for the Coordination of Defence Sir Thomas Inskip saw no reason why Britain "should take any steps to maintain such a unit [Czechoslovakia] in being."23 Commenting on the French declaration guaranteeing the independence of Czechoslovakia, the prime minister wondered "whether it would not be possible to make some arrangement which would prove more acceptable to Germany."

In a speech to the Commons on 24 March 1938, Churchill urged stronger links to France and warned about the future of Czechoslovakia:

Czechoslovakia will be forced to make continuous surrenders, far beyond the bounds of what any impartial tribunal would consider just or right, until finally her sovereignty, her independence, her integrity, have been destroyed. ${ }^{25}$

Churchill understood that Britain's reaction to the Anschluss was a prologue to the greater tragedy that was to befall Czechoslovakia in the near future. Six months later, Munich proved him right.

\section{Munich, 1938}

On 2-3 September 1938, Germany declared full mobilization, and Hitler warned that Sudeten Germans needed protection from their Czech rulers. On 2 September, Ivan Maisky, the Soviet ambassador to Britain, drove to see Churchill at his home in Chartwell. There Maisky told Churchill that the Soviet government wished to invoke Article II of the Covenant of the League of Nations, under which all powers, including Britain, France, and the Soviet Union, were obliged to consult to prevent an impending war. He wanted to explore a joint resolution and a course of action defending Czechoslovakia against an imminent German attack. On the following day Churchill sent Lord Halifax an account of this conversation, but the foreign secretary did not think that Article II "would be helpful." HMG did not wish to become allied with Russia against Germany. ${ }^{26}$ On 7 September 1938, the London Times, which enthusiastically supported Chamberlain's policies of appeasement, editorialized in favor of separating the Sudetenland from Czechoslovakia. On 9 September, while German troops massed on the Czech frontier, Chamberlain decided to seek negotiations with Hitler, while excluding the Czechs. 
Unaware of Chamberlain's decision of 9 September, Churchill went to Downing Street to rally the prime minister and the foreign secretary against the German aggression. Sir Samuel Hoare, who had once been foreign secretary and was at the time home secretary, recalled that "he had come to demand an immediate ultimatum to Hitler. He was convinced it was our last chance of stopping a landslide." ${ }^{27}$ That night Churchill also called Lord Halifax, not knowing that the foreign secretary had already backed the PM and had warned the French that Great Britain would not support France in case of war with Germany. While Churchill had advocated for a tripartite alliance against Hitler, consisting of Britain, France, and the Soviet Union, Lord Halifax's aim was to sever all British ties from such a pact. ${ }^{28}$ On 11 September, Churchill returned to urge the prime minister and his foreign secretary to warn Germany "that if she set foot in Czechoslovakia we should at once be at war with her." ${ }^{29}$ This course of action was far from what Chamberlain and Lord Halifax had in mind.

On 15 September, Chamberlain flew to Berchtesgaden for the first of three meetings. There he assured Hitler that he was not opposed to the Sudetenland's joining Germany and would support a plebiscite of its German-speaking inhabitants. On 21 September, the British and French pressured President Edvard Beneš to agree to the transfer of the Sudetenland to Germany. They made it clear that they would not support Czechoslovakia should Germany invade. By then France was divided, and, like Britain, intent on a policy of appeasement.

On 22 September, Chamberlain flew to Bad Godesberg to assure Hitler that the British and French had decided to support a plebiscite in Sudetenland and were ready for the transfer of this territory to Germany should the vote favor it. Seeing that he had Chamberlain on the run, Hitler demanded the immediate transfer of the Sudetenland to Germany. On the second day of the meeting, Chamberlain caved in. He agreed that there would be no plebiscite where the Germans constituted a majority, and he acceded to the transfer of all Czech fortifications and war materiel to the Germans.

Addressing the Commons on 28 September 1938, Neville Chamberlain expressed his reluctance to help avert the destruction of Czechoslovakia by the Nazis: "How horrible, fantastic, incredible it is that we should be digging trenches and trying on gas masks here because of a quarrel in a faraway country between people of whom we know nothing."30

On 29 September, Chamberlain flew to Munich at Hitler's invitation to attend a four-power conference consisting of Germany, Britain, France, and Italy. Twelve hours later they agreed that the German occupation of the German-speaking areas of the Sudetenland would begin on the next day. The Czech delegation, though present in Munich, was not party to the discussions. What happened in Munich in 1938 constituted a major political and military victory for the Nazis. They would take over the Škoda Works, one of Europe's major armament-producing installations, and the democracies' military strength would be reduced by thirty divisions. These were resources and weapons that would be trained on Britain and her allies in less than a year.

Three days after Munich, in answer to some pointed criticism in the Commons from Duff Cooper and other anti-appeasers, Chamberlain said,

Ever since I assumed my present office my main purpose has been to work for the pacification of Europe, for the removal of those suspicions and those animosities which have so long poisoned the air. The path which leads to appeasement is long and bristles with obstacles. The question of Czechoslovakia is the latest and perhaps the most 
dangerous. Now that we have got past it, I feel that it may be possible to make further progress along the road to sanity. ${ }^{31}$

Speaking in the Commons on 5 October 1938, Churchill had a very different take on what had happened in Munich:

I shall begin by saying what everybody would like to ignore or forget but which must nevertheless be said, namely, that we have sustained a total and unmitigated defeat, and that France has suffered even more than we have ...

All is over. Silent, mournful, abandoned, broken, Czechoslovakia recedes into the darkness. She has suffered in every respect by her association with the Western democracies and with the League of Nations, of which she was always an obedient servant....

I venture to think that in future the Czechoslovak state cannot be maintained as independent entity. You will find that in a period of time which may be measured in years, but may be measured only by months, Czechoslovakia will be engulfed by the Nazi regime.

But we cannot consider the abandonment and ruin of Czechoslovakia in the light only of what happened last month. It is the most grievous consequence which we have yet experienced of what we have done and what we have left undone in the last five years-five years of futile good intention, five years of eager search for the line of least resistance, five years of uninterrupted retreat of British power, five years of neglect of our air defences. Those are the features which I stand here to declare and which marked an improvident stewardship for which Great Britain and France have dearly to pay ...

We are in the presence of a disaster of the first magnitude which has befallen Great Britain and France. Do not let us blind ourselves to that. It must now be accepted that all the countries of Central and Eastern Europe will make the best terms they can with the triumphant Nazi power ...

You will see, day after day, week after week, entire alienation of those regions. Many of those countries, in fear of the Nazi Power, have already got politicians, Ministers, Governments, who were pro-German, but there was always an enormous popular movement in Poland, Rumania, Bulgaria, and Yugoslavia which looked to the Western democracies and loathed the idea of having the arbitrary rule of the totalitarian system thrust upon them, and hoped that a stand would be made. All that has gone by the board. We are talking of countries which are a long way off and of which, as the Prime Minister might say, we know nothing... .

And do not suppose that this is the end. This is only the beginning of the reckoning. This is only the first sip, the first foretaste of a bitter cup which will be proffered to us year by year unless by a supreme recovery of moral health and martial vigour, we arise again and take our stand for freedom as in the olden time. ${ }^{32}$

German forces marched into Prague on 15 March 1939. Bohemia and Moravia were declared protectorates in which ethnic Germans became German citizens and Czechs were defined as protectorate nationals. On 27 April Britain declared general conscription, and Germany declared the nullification of its 1935 naval pact with Britain. On 23 August the signing of the Molotov-Ribbentrop Pact, scheduled to last for ten years, laid out the partition of Poland between Germany and the Soviet Union. On 1 September 1939, Germany invaded Poland; on 3 September, Britain and France declared war on Germany. On 10 May 1940, Germany invaded Belgium, Luxembourg, 
and the Netherlands. On the same day, Neville Chamberlain resigned and Winston Churchill became prime minister.

\section{Conclusion}

Churchill believed that had he been prime minister of Britain during the Rhineland crisis in 1936 or in Munich in 1938, war might have been averted even at this late date. Most historians, like Christopher Browning, suggest that World War II, and especially the invasion of the Soviet Union in 1941, set the stage for the Holocaust. ${ }^{33}$ Hence it is reasonable to infer that had the war been averted, the Holocaust would also have been prevented.

Indeed, even had war broken out in 1938, though it might very well have provided a context for countless atrocities against Jews and others, the Holocaust as we know it likely would not have occurred. The Munich crisis preceded the euthanasia program, which began in 1939, and the use of Zyklon B in 1941; it preceded the death camps at Auschwitz, Belzec, Chelmno, Majdanek, Sobibor, and Treblinka; it preceded the McDonald White Paper of 17 May 1939 and the closing off of Palestine as an escape route for Jews. Despite the Nazis' intention to destroy the Jews, the initial conditions of 22 June 1941-the incredible early victories and the enthusiasm of the moment when everything seemed possible, including genocide-would not have occurred, and the Final Solution would have remained an ideological vision rather than the very real catastrophe that we know.

However, had Churchill been able to avert World War II and the Holocaust, it is unlikely that he would have been credited with preventing these two catastrophes. Herein lies the irony, or the paradox, of prevention: because these events would have been prevented, no one would have known their cost. The only thing Britons would have known was the dangerous course that Churchill had navigated in Munich and the risk he had run of provoking another world war. Before the war, although many admired him, others saw him as an imperialist and as a dangerous adventurer who lacked political judgment. Such views plagued him and undermined him politically, beginning with the debacle of Gallipoli in 1915, for which he was wrongly accused of having had sole responsibility, and continuing through his political blunders of the 1930s, which included opposing Dominion status for India and supporting Edward VIII through his abdication. ${ }^{34}$ Standing up to Hitler in Munich, even if successful, might have been viewed as a dangerous and foolish adventure that could have precipitated war. Indeed, Churchill and his party might have gone down to defeat after preventing both World War II and the Holocaust.

The lesson of Churchill and World War II is not that leaders who threaten the international order must always be resisted by force, never appeased or mollified. Some situations do call for caution, diplomacy, and even appeasement. I suspect that most Americans today would have preferred that the United States not pursue a preventive war against Iraq; President Dwight David Eisenhower's refusal to attack the Soviet Union in 1956, during the Hungarian revolution, to avoid a nuclear exchange and his warning to the United States about getting bogged down in a land war in Asia seem wise in retrospect. Indeed, Churchill, himself did not advocate war with Germany. On the contrary, his strategy was to create a powerful coalition of states, including Britain, France, and the Soviet Union, with the aim of deterring German expansion and preventing the war and the destruction that he believed would follow. 
What were Churchill's own thoughts on the matter of prevention? Despite his hope that future generations might learn from experience, a hope he expressed to Roosevelt when he called World War II the "unnecessary war," Churchill was pessimistic about the ability of leaders to foretell the future and thus prevent looming catastrophes. As early as 25 March 1935, speaking to the House of Commons about German rearmament, he warned about the "unteachability of mankind":

When the situation was manageable it was neglected, and now that it is thoroughly out of hand, we apply too late the remedies which then might have effected a cure. There is nothing new in the story. It is as old as the sibylline books. It falls into that long dismal catalogue of the fruitlessness of experience and the confirmed unteachability of mankind. Want of foresight, unwillingness to act when action would be simple and effective, lack of clear thinking, confusion of counsel until the emergency comes, until self-preservation strikes its jarring gong-these are the features which constitute the endless repetition of history. ${ }^{35}$

To Churchill's pessimistic assessment of the "unteachability of mankind" I have tried to add the "paradox of prevention" as an obstacle to action. Even when leaders can be persuaded that they may be able to prevent genocide, the paradox suggests that they will not be rewarded for their efforts, and, knowing this, they will hesitate to act. However, this analysis may be too narrow and too closely tied to a cost/benefit model of decision making. Sometimes leaders do rise to the occasion, and, despite the costs to their political fortunes, they do attempt to prevent war and genocide. Churchill himself is a prime example. His political situation in the 1930s would have improved markedly had he gone along with the Baldwin/Chamberlain strategy of appeasement. But he acted out of moral considerations, mainly for the benefit of Britain and the Empire. What we need for our time are leaders and populations with the will and the broad moral vision to transcend narrow self and national interest, who are willing to act in order to prevent the mass murder of people, whoever they are wherever they may live. ${ }^{36}$ That vision should include even those "who live in another country," as Chamberlain remarked, and "of whom we know nothing."

\section{Acknowledgments}

A version of this article was presented at the Lessons and Legacies Conference on the Holocaust, Yad Vashem, Jerusalem, Israel, 19-20 December 2007. I wish to thank Professors Yehuda Bauer, Deborah Dwork, and Jacques Kornberg for helpful comments.

\section{Notes}

1. Even after the Rwandan genocide began in April 1994, neither the United States nor Belgium nor any other Western power, nor the United Nations, acted to prevent the destruction of the Tutsi minority. France later intervened (through Opération Turquoise) not to save Tutsi lives but to protect the Hutu power structure and prevent the Rwandan Patriotic Front (RPF) from seizing power. Samantha Power, "A Problem from Hell":

America and the Problem of Genocide (New York: Basic Books, 2002), 329-90. Events in Rwanda may have shocked the Clinton administration, with consequences for the later US-led intervention in Kosovo. See also Peter Ronayne, Never Again? The United States and Punishment of Genocide Since the Holocaust (New York: Rowman \& Littlefield, 2001). The intervention of Australia and other countries to suppress the violence in East Timor may be an anomaly. See Alan Ryan, "The Strong Lead-Nation Model in an Ad Hoc Coalition of the Willing: Operation Stabilise in East Timor," International Peace Keeping 1 (2002): 23-44; James Cotton, "Against the Grain: The East Timor Intervention," Survival 
43 (2001): 127-42. For an overview and extensive bibliography on the subject of prevention see Samuel Totten, The Prevention and Intervention of Genocide (London: Routledge, 2006).

2. Power, A Problem from Hell, 508.

3. Counterfactual examples like the ones proposed here rest on a theory of history that views events as partially guided by human choices and not predetermined by social forces. As Isaiah Berlin has noted, "[All] discussions of historians about whether a given policy could or could not have been prevented ... are intelligible only on the assumption of the reality of human choices. If determinism were a valid theory of human behavior, these distinctions would be as inappropriate as the attribution of moral responsibility to the planetary system or the tissues of a living cell." Isaiah Berlin, Theories of History, ed. Patrick Gardiner (Glencoe, NY: The Free Press, 1963), 321. See also Niall Ferguson, ed., Virtual History (New York: Basic Books, 1999).

4. Winston S. Churchill, The Gathering Storm, vol. 1 of The Second World War (Cambridge, MA: Riverside Press, 1948; reprint, New York: Mariner Books, 1976), 279-82.

5. The link between World War II, particularly the invasion of the Soviet Union in 1941, and the Holocaust is made by a number of historians, most notably Christopher Browning, who writes that "Nazi racial policy was radicalized at points in time that coincided with the peaks of German military success, as the euphoria of victory emboldened and tempted an elated Hitler to dare ever more drastic policies. With the 'war of destruction' in the Soviet Union underway and the imminent prospect of all Europe at his disposal, the last inhibitions fell away." Christopher Browning, The Origins of the Final Solution (Lincoln: University of Nebraska Press, 2004), 427. See also Ian Kershaw, Hitler, 1936-1945: Nemesis (New York: W.W. Norton, 2000), 459; Doris L. Bergen, War and Genocide: A Concise History of the Holocaust (New York: Rowman \& Littlefield, 2003), 149. For earlier controversies about the origins of the Holocaust see Robert Melson, Revolution and Genocide: On the Origins of the Armenian Genocide and the Holocaust (Chicago: University of Chicago Press, 1992), 5-10; Michael Marrus, The Holocaust and History (Hanover, NH: University Press of New England, 1987), 31-54.

6. Andrew Roberts and Niall Ferguson, "Hitler's England: What If Germany Had Invaded Britain in May 1940?" in Virtual History, ed. Niall Ferguson, 281-320 (New York: Basic Books, 1999).

7. Churchill, The Gathering Storm, xiv.

8. William Manchester, The Last Lion: Alone, 1932-1940 (New York: Delta Books, 1988), 51.

9. Ibid., 67.

10. In the summer of 1932 Churchill visited Munich to research the Duke of Marlborough, his great ancestor. He stayed at the Regina Hotel. It was on this visit that he almost met Hitler. Ernst "Putzi" Hanfstaengel—a Nazi sympathizer and admirer of Hitler, and a Harvard graduate whose mother was American-tried to arrange a meeting between Churchill and the Führer. Churchill thwarted Putzi's plans when he asked him about Hitler's anti-Semitism: "Why is your chief so violent about the Jews ... what is the sense of being against a man simply because of his birth? How can any man help how he is born? Tell your boss for me that antisemitism may be a good starter, but it is a bad stayer." The next day Putzi informed Churchill that Hitler had other plans. Manchester, Alone, 66-67.

11. Ibid., 46.

12. Ibid., 68; London Times, 18 February 1933.

13. Manchester, Alone, 135.

14. Ibid., 136.

15. Winston S. Churchill (grandson), ed., Never Give In: The Best of Winston Churchill's Speeches (New York: Hyperion, 2003), 125-28.

16. Ibid., 130, 131.

17. Ibid., 130-33.

18. Ibid., 130-33. 
19. Ibid., 159-60; see also Martin Gilbert, Churchill: A Life (New York: Henry Holt, 1991), 589.

20. Churchill, Never Give In, 161; Gilbert, Churchill, 589.

21. Churchill, Never Give In, 162-63; Gilbert, Churchill, 590.

22. Churchill, Never Give In, 163.

23. Gilbert, Churchill, 591.

24. Ibid.

25. Ibid., 592.

26. Ibid., 594.

27. Ibid., 595.

28. Ibid.

29. Ibid.

30. Manchester, Alone, 345; London Times, 28 September 1938.

31. Gilbert, Churchill, 598.

32. Churchill, Never Give In, 172 (“... even more than we have”), 175 (“... an obedient servant”), 176 (“. . engulfed by the Nazi regime”), 176 (“... France have dearly to pay”), 178 (“... triumphant Nazi power"), 182 (“... as in olden time").

33. Browning, Origins of the Final Solution, 427; Kershaw, Hitler, 1936-1945, 459; Bergen, War and Genocide, 149; Melson, Revolution and Genocide, 5-10; Marrus, Holocaust and History, 31-54.

34. On Gallipoli see Gilbert, Churchill, 367; Alan Moorehead, Gallipoli (New York: Harper \& Brothers, 1956), 349-62; William Manchester, The Last Lion: Visions of Glory, 1874-1932 (New York: Delta Books, 1983), 524-49.

35. Manchester, Alone, 137.

36. See Herbert Hirsch, Anti-Genocide: Building an American Movement to Prevent Genocide (Westport, CT: Praeger, 2002); David A. Hamburg, No More Killing Fields: Preventing Deadly Conflict (New York: Rowman \& Littlefield, 2002). 